\title{
Acute dural venous thrombosis
}

\author{
Joshua Paul Harvey, ${ }^{1}$ Maam Mamun ${ }^{2}$
}

${ }^{1}$ Stroke Department, Medway Maritime Hospital, Gillingham, UK

${ }^{2}$ Medway Maritime Hospital, Gillingham, UK

\section{Correspondence to} Dr Joshua Paul Harvey, harveyjoshua90@gmail.com

Accepted 3 September 2015

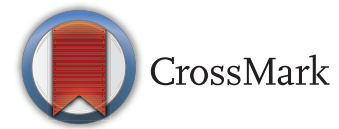

To cite: Harvey JP, Mamun M. BMJ Case Rep Published online: [please include Day Month Year] doi:10.1136/bcr-2015212437

\section{DESCRIPTION}

An 18-year-old female student presented with a 7-day history of worsening frontal headache and 1 day history of vomiting. The patient described marked photophobia, but no fever or history of seizure. She was taking a combined oral contraceptive and had no other medical history. Physical examination showed no focal neurology, but funduscopy revealed bilateral papilloedema. On admission, a non-contrast CT of the head showed a hyperdense

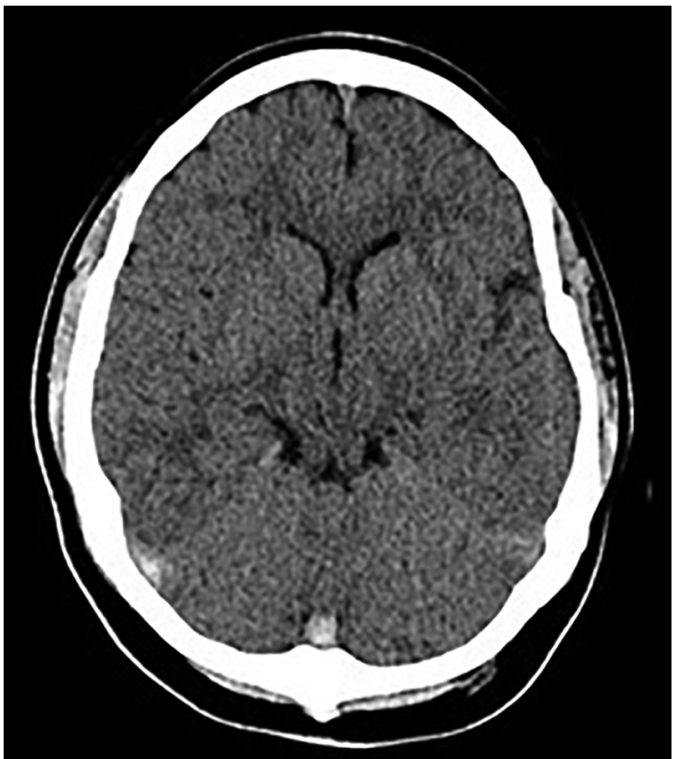

Figure 1 Non-contrast CT scan demonstrating the triangle sign.

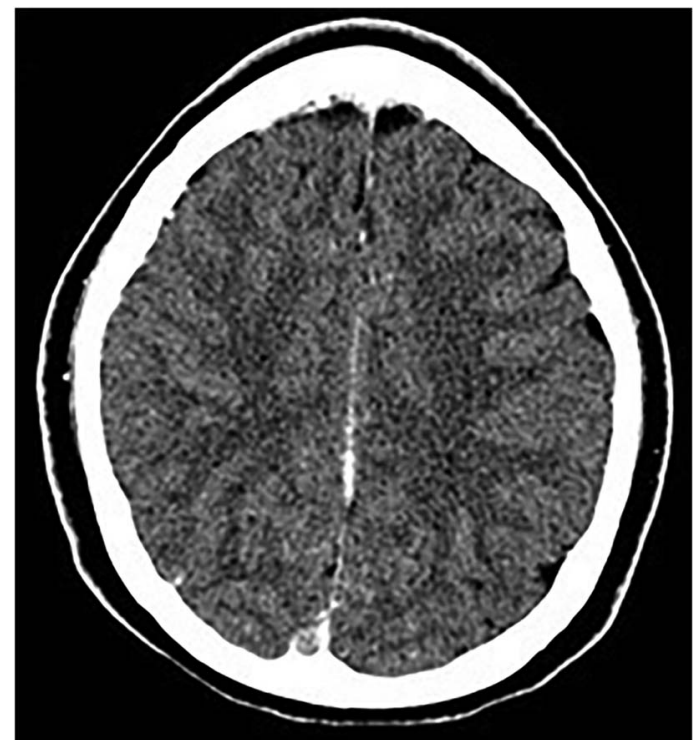

Figure 2 Contrast CT scan demonstrating the $\delta$ sign.

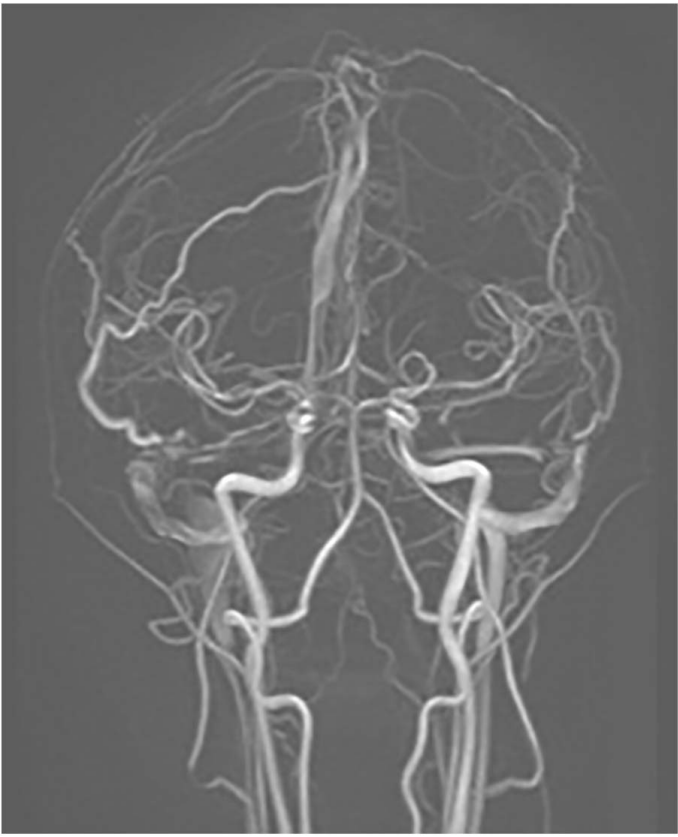

Figure 3 MR venogram demonstrating a filling defect of the superior sagittal vein.

thrombus, triangle sign (figure 1) and prominence of the superior sagittal, straight, right transverse and sigmoid sinuses-highly suggestive of acute cerebral dural sinus thrombosis. Contrast CT demonstrated a $\delta$ sign, contrast outlining a filling defect due to a thrombus (figure 2). MR venogram (MRV) (figure 3) confirmed diagnosis and demonstrated little cerebral oedema, and no bleed or haemorrhagic infarction. The patient was treated with heparin and discharged on warfarin. Review after 4 months showed healthy discs with no papilloedema; the warfarin was

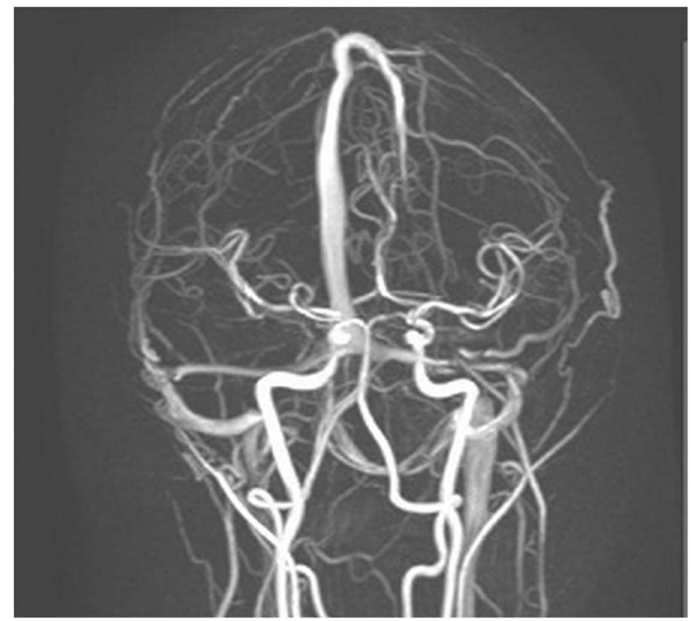

Figure 4 Repeat MR venogram demonstrating recanalisation of the superior sagittal vein. 


\section{Learning points}

Acute dural venous thrombosis represents around $0.5-1 \%$ of all strokes.

- Non-contrast CT scan may be normal but contrast CT scan classically shows a $\delta$ sign: a contrast filling defect in the superior sagittal vein.

- Always enquire about the use of an oral contraceptive in a young woman presenting with an acute onset headache.

stopped due to recurrent epistaxis and repeat MRI/MRV showed good re-canalisation (figure 4).

Dural venous thrombosis represents $0.5-1 \%$ of all strokes and has an incidence of around 5 per million people per year. ${ }^{1}$ Presenting symptoms include: headache, papilloedema, cranial nerve palsies, unilateral motor weakness and speech disturbances. ${ }^{1}$ Non-contrast CT scans are often normal but may demonstrate a triangle sign (figure 1). Contrast CT may show a $\delta$ sign, a contrast filling defect in the superior sagittal vein (figure 2). ${ }^{2}$ MRV remains the gold standard imaging technique of dural sinus thrombosis. ${ }^{2}$ The mainstay of treatment is anticoagulation. ${ }^{1}$ The ISCVT study demonstrated a $8.3 \%$ mortality and $79 \%$ of patients make a full recovery. ${ }^{3}$

Twitter Follow Maam Mamun at @anis_mamun

Contributors MM was jointly involved in the immediate and follow-up care of the patient as well as the review of this manuscript for submission.

Competing interests None declared.

Patient consent Obtained.

Provenance and peer review Not commissioned; externally peer reviewed.

\section{REFERENCES}

1 Saposnik G, Barinagarrementeria F, Brown RD Jr, et al. Diagnosis and management of cerebral venous thrombosis: a statement for healthcare professionals from the American Heart Association/American Stroke Association. Stroke 2011;42:1158-92.

2 Justich E, Lammer J, Fritsch G, et al. CT diagnosis of thrombosis of dural sinuses in childhood. Eur J Radiol 1984;4:294-5.

3 Miranda B, Ferro JM, Canhão P, et al., ISCVT Investigators. Venous thromboembolic events after cerebral vein thrombosis. Stroke 2010;41:1901-6.

Copyright 2015 BMJ Publishing Group. All rights reserved. For permission to reuse any of this content visit

http://group.bmj.com/group/rights-licensing/permissions.

BMJ Case Report Fellows may re-use this article for personal use and teaching without any further permission.

Become a Fellow of BMJ Case Reports today and you can:

- Submit as many cases as you like

- Enjoy fast sympathetic peer review and rapid publication of accepted articles

- Access all the published articles

- Re-use any of the published material for personal use and teaching without further permission

For information on Institutional Fellowships contact consortiasales@bmjgroup.com

Visit casereports.bmj.com for more articles like this and to become a Fellow 